\title{
Activation of Human Factor IX (Christmas Factor)
}

\author{
Richard G. Di Scipio, Kotoku Kurachi, and Earl W. Davie, Department of \\ Biochemistry, University of Washington, Seattle, Washington 98195
}

A B S T RA C T Human Factor IX (Christmas factor) is a single-chain plasma glycoprotein ( $\mathrm{mol}$ wt 57,000$)$ that participates in the middle phase of the intrinsic pathway of blood coagulation. It is present in plasma as a zymogen and is converted to a serine protease, Factor $\mathrm{IX}_{\mathrm{a} \beta}$, by Factor $\mathrm{XI}_{\mathrm{a}}$ (activated plasma thromboplastin antecedent) in the presence of calcium ions. In the activation reaction, two internal peptide bonds are hydrolyzed in Factor IX. These cleavages occur at a specific arginyl-alanine peptide bond and a specific arginyl-valine peptide bond. This results in the release of an activation peptide ( $m o l$ wt $\cong 11,000$ ) from the internal region of the precursor molecule and the generation of Factor $\mathrm{IX}_{\mathrm{a} \beta}(\mathrm{mol}$ wt $\cong 46,000)$. Factor $\mathrm{IX}_{\mathrm{a} \beta}$ is composed of a light chain ( $\left.\mathrm{mol} \mathrm{wt} \cong 18,000\right)$ and a heavy chain ( $m o l$ wt $\cong 28,000$ ), and these chains are held together by a disulfide bond(s). The light chain originates from the amino terminal portion of the precursor molecule and has an amino terminal sequence of Tyr-Asn-Ser-Gly-Lys. The heavy chain originates from the carboxyl terminal region of the precursor molecule and contains an amino terminal sequence of Val-Val-Gly-Gly-Glu. The heavy chain of Factor $\mathrm{IX}_{\mathrm{a} \beta}$ also contains the active site sequence of Phe-Cys-Ala-Gly-Phe-His-Glu-Gly -Gly -Arg -Asp -Ser Cys-Gln-Gly-Asp-SER-Gly-Gly-Pro. The active site serine residue is shown in capital letters. Factor IX is also converted to Factor IX $_{\mathrm{a} \alpha}$ by a protease from Russell's viper venom. This activation reaction, however, occurs in a single step and involves only the cleavage of the internal arginyl-valine peptide bond. Human Factor $\mathrm{IX}_{\mathrm{a} \beta}$ was inhibited by human antithrombin III by the formation of a one-to-one complex of enzyme and inhibitor. In this reaction, the inhibitor was tightly bound to the heavy chain of the enzyme. These data indicate that the mechanism of activation of human Factor IX and its inhibition by antithrombin III is essentially identical to that previously shown for bovine Factor IX.

Received for publication 25 November 1977 and in revised form 6 February 1978.

\section{INTRODUCTION}

Human Factor IX (Christmas factor $)^{1}$ is one of the three vitamin K-dependent plasma proteins that participate in the intrinsic pathway of blood coagulation (1). During the generation of fibrin, Factor IX, a zymogen, is converted to a serine protease called Factor IX $_{\mathrm{a}}$. In the presence of Factor VIII $_{a}$ (activated antihemophilic factor), phospholipid, and calcium ions, Factor IX $_{\mathrm{a}}$ then converts Factor $\mathrm{X}$ (Stuart factor) to Factor $\mathrm{X}_{\mathrm{a}}$.

The purification of human Factor IX has been reported by a number of different investigators (2-7). It is a single-chain glycoprotein with mol wt 57,000 . Human Factor IX, as well as bovine Factor IX, also contains $\gamma$-carboxyglutamic acid which is characteristic of the vitamin K-dependent proteins $(8,9)$.

The activation of bovine Factor IX by bovine Factor $\mathrm{XI}_{\mathrm{a}}$ (activated plasma thromboplastin antecedent) occurs in two steps $(10,11)$. In the first step, a specific internal peptide bond is cleaved giving rise to a twochain intermediate held together by a disulfide bond(s). This intermediate does not have enzymatic activity. In the next step, a second specific peptide bond in the amino terminal region of the heavy chain is cleaved giving rise to Factor $\mathrm{IX}_{\mathrm{a} \beta}$ and an activation peptide. Bovine Factor IX is also activated by a protease from Russell's viper venom (RVV-X) ${ }^{2}$ in a single-step reaction (11). In this reaction, Factor IX is activated by the cleavage of an internal arginyl-valine bond generating Factor $\operatorname{IX}_{\mathrm{a} \alpha}(11)$. Recently, $\emptyset$ sterud and Rapaport (12) have reported the activation of human Factor IX by Factor VII and thromboplastin. The details of this activation mechanism, however, have not been defined thus far.

Studies by a number of investigators have shown

\footnotetext{
${ }^{1}$ The nomenclature for the various clotting factors is that recommended by an international nomenclature committee (13). The nomenclature for activated Factor IX is that of Lindquist et al. (11).

${ }^{2}$ Abbreviations used in this paper: DFP, diisopropylphosphorofluoridate; RVV-X the protease from Russell's viper venom that activates Factor $\mathrm{X}$.
} 
that the activation of human Factor IX by human Factor $\mathrm{XI}_{\mathrm{a}}$ is similar to that of the bovine system $(5,14)$. The details of this reaction, however, have not been defined. The primary objective of this work has been to investigate in detail the mechanism of activation of human Factor IX by human Factor $\mathrm{XI}_{\mathrm{a}}$.

\section{METHODS}

Human Factor IX was purified to homogeneity by a slight modification of the method of Di Scipio et al. (7). In the present experiments, a single $0-40 \%$ ammonium sulfate precipitation was substituted for the sequential $0-10 \%$ and $10-40 \%$ ammonium sulfate precipitations. The protease from RVV-X that activates Factor IX was purified to homogeneity by the method of Kisiel et al. (15).

Barbital, urethane, imidazole (grade I), 2-( $N$-morpholino)ethane sulfonic acid, Coomassie Brilliant Blue $\mathbf{R}$ stain, glucosamine, dithiothreitol, aldolase, bovine serum albumin, bovine carbonic anhydrase, and myoglobin were obtained from Sigma Chemical Co., St. Louis, Mo. Sodium dodecyl sulfate, sodium arsenate, and 4-vinylpyridine were obtained from J. T. Baker Chemical Co., Phillipsburg, N. J. The 4vinylpyridine was vacuum distilled before use. Periodic acid was a product of Frederick Smith Chemical Co., Columbus, Ohio, and 2-thiobarbituric acid, 2-mercaptoethanol, $N, N^{\prime}$ methylenebisacrylamide, iodoacetic acid, and $N, N, N^{\prime} N^{\prime}$ tetraethylenediamine were purchased from Eastman Kodak Co., Rochester, N. Y. Agarose was a product of Marine Colloids, Inc., Rockland, Maine. Sodium lauryl sulfate was purchased from BDH Chemicals Ltd., Poole, England, and acrylamide was obtained from Bio-Rad Laboratories, Richmond, Calif. Cyclohexanone was a product of Aldrich Chemical Co., Inc., Milwaukee, Wis. Lithium heparin (151 $\mathrm{U} / \mathrm{mg}$ ), prepared from porcine intestinal mucosa, was obtained from Riker Laboratories, Inc., Northridge, Calif. Sephadex G-75 superfine, Sephadex G-50 superfine, and Sephadex G-25 coarse were products of Pharmacia Fine Chemicals, Piscataway, $\mathrm{N}$. J. Constant boiling $\mathrm{HCl}$ and cyanogen bromide were obtained from Pierce Chemical Co., Rockford, Ill. Phosphorylase $\boldsymbol{b}$ was kindly provided by Dr. E. Fischer, University of Washington. Human antithrombin III was prepared by the method of Kurachi et al. (16). Carboxypeptidases A and B were products of Worthington Biochemical Corp., Freehold, N. J., and were treated with $1 \mathrm{mM}$ diisopropylphosphorofluoridate (DFP) before use. Normal human plasma was obtained from the Puget Sound Blood Center, Seattle, Wash. It was stored for $\cong 6 \mathrm{mo}$ at $-20^{\circ} \mathrm{C}$ before use. Inosithin was a product of Associated Concentrates, Woodside, L. I., N. Y.

RVV-X-and trypsin-Sepharose were prepared by incubating $20 \mathrm{mg}$ of $\mathrm{RVV}-\mathrm{X}$ or trypsin in $20 \mathrm{ml}$ of $0.1 \mathrm{M}$ sodium bicarbonate containing $1.0 \mathrm{M} \mathrm{NaCl}$ overnight with $20 \mathrm{ml}$ of a Sepharose 4B slurry previously activated with cyanogen bromide (17).

Human Factor $\mathrm{XI}_{\mathrm{a}}$ was prepared from a homogeneous preparation of Factor XI (18) as follows: Factor XI $(80 \mu \mathrm{g})$ in $100 \mu \mathrm{l} 50 \mathrm{mM}$ Tris-HCl buffer, $\mathrm{pH} 7.8$ containing $0.15 \mathrm{M}$ $\mathrm{NaCl}$ was added to $25 \mu \mathrm{l}$ of trypsin-Sepharose previously equilibrated with the same buffer. The reaction mixture was incubated for $25 \mathrm{~min}$ at $30^{\circ} \mathrm{C}$ with rapid swirling. The trypsin-Sepharose was then removed by centrifugation for $1 \mathrm{~min}$ at $500 \mathrm{~g}$ and the Factor $\mathrm{XI}_{\mathrm{a}}$ was used immediately to activate Factor IX.

Protein concentration was determined by absorption at 280 $\mathrm{nm}$. An extinction coefficient of $E_{280}^{1 \%}=13.3$ was employed for Factor IX (7), and this same value was assumed for
Factor IX $\mathrm{IX}_{\mathrm{a}}$. An $E_{280}^{1 \%}=5.7$ was employed for human antithrombin III (16), and an $E_{280}^{1 \%}=13.4$ was assumed for human Factor $\mathrm{XI}_{\mathrm{a}}$ (18).

Amino acid and carbohydrate analyses and preparation of samples were carried out by the methods described (19-28).

Sodium dodecyl sulfate-polyacrylamide gel electrophoresis was performed by the method of Weber and Osborn (29) as modified by Kisiel et al. (15). The gels were run for 3-4 h at 4.2 $\mathrm{mA} / \mathrm{gel}$ and were stained for protein with a $0.2 \%$ solution of Coomassie Brilliant Blue: The gel containing the activation peptide was first fixed in $12.5 \%$ trichloroacetic acid for $1 \mathrm{~h}$ before staining. Molecular weights were estimated by interpolation from a linear semilogarithmic plot of molecular weight vs. migration distance with the following protein standards: phosphorylase $b(97,000)$, bovine serum albumin $(68,000)$, aldolase $(40,000)$, bovine carbonic anhydrase $(29,000)$, and myoglobin $(17,000)$.

Activation of Factor IX by Factor $X I_{a}$ and RVV-X Sepharose. Human Factor IX (10 mg) in $10 \mathrm{ml}$ of $0.05 \mathrm{M}$ Tris- $\mathrm{HCl}$ buffer, pH 7.8, containing $0.15 \mathrm{M} \mathrm{NaCl}$ and $5 \mathrm{mM} \mathrm{CaCl}_{2}$ was activated at $37^{\circ} \mathrm{C}$ by the addition of $0.13 \mathrm{mg}$ Factor $\mathrm{XI}_{\mathrm{a}}$. The enzyme-tosubstrate weight ratio varied from 1:50 to $1: 80$. The reaction was terminated by the addition of EDTA to a final concentration of $10 \mathrm{mM}$. For coagulant assays, samples $(10 \mu \mathrm{l})$ were withdrawn at various times from the reaction mixture and diluted 100- to 1,000-fold with cold Michaelis buffer $(36 \mathrm{mM}$ sodium acetate, $36 \mathrm{mM}$ sodium barbital, and $0.145 \mathrm{M}$ sodium chloride, $\mathrm{pH} 7.4)$ containing bovine serum albumin $(0.1$ $\mathrm{mg} / \mathrm{ml})$. An aliquot $(0.1 \mathrm{ml})$ of the diluted sample was then incubated at $37^{\circ} \mathrm{C}$ for $1 \mathrm{~min}$ with $0.1 \mathrm{ml}$ of $0.08 \%$ inosithin suspension and $0.1 \mathrm{ml}$ of normal human plasma in a siliconized glass tube. The clotting time was determined after the addition of $0.1 \mathrm{ml}$ of $0.033 \mathrm{M} \mathrm{CaCl}_{2}$. The percent activation of Factor IX was determined from a calibration curve prepared from the fully activated sample.

Factor IX $(0.056 \mathrm{mg})$ in $0.07 \mathrm{ml}$ of $0.05 \mathrm{M}$ Tris-HCl buffer, $\mathrm{pH} 7.8$, containing $0.15 \mathrm{M} \mathrm{NaCl}$ and $10 \mathrm{mM} \mathrm{CaCl}_{2}$ was activated by the addition of $20 \mu \mathrm{l}$ of RVV-X Sepharose suspension followed by rapid swirling throughout the incubation at $37^{\circ} \mathrm{C}$. At various times, the reaction was terminated by the addition of $10 \mu \mathrm{l}$ of $0.2 \mathrm{M}$ EDTA and the tube was centrifuged for $1 \mathrm{~min}$ at $500 \mathrm{~g}$ to remove the RVV-X-Sepharose. Factor $\mathrm{IX}_{\mathrm{a}}$ in the supernatant fraction was then assayed as described above.

The effect of DFP on Factor $\mathrm{IX}_{\mathrm{a} \beta}$ was tested by incubating freshly prepared Factor $\mathrm{IX}_{\mathrm{a} \beta}$ in $0.05 \mathrm{M}$ Tris- $\mathrm{HCl}$ buffer, $\mathrm{pH}$ 7.8 , containing $0.15 \mathrm{M} \mathrm{NaCl}$ and $5 \mathrm{mM} \mathrm{CaCl}_{2}$ with $1 \mathrm{mM}$ to 5 $\mathrm{mM}$ DFP for $1 \mathrm{~h}$ at $37^{\circ} \mathrm{C}$. Esterase assays for human Factor $\mathrm{IX}_{\mathrm{a} \beta}$ were carried out by the method of Roffman et al. (30) as described by Kurachi et al. (31) using $\mathrm{L}\left[{ }^{3} \mathrm{H}\right]$ tosyl arginine methyl ester as a substrate.

The heavy and light chains of human Factor IX $_{\mathrm{a}}$ and the activation peptide were prepared as follows: Factor IX $(10 \mathrm{mg})$ was incubated with Factor $\mathrm{XI}_{\mathrm{a}}(0.15 \mathrm{mg})$ for $75 \mathrm{~min}$ in the presence of $5 \mathrm{mM}$ calcium chloride as previously described and the reaction was terminated by the addition of $1 \mathrm{ml}$ of 0.2 M EDTA. The protein was then desalted on a Sephadex G25 column $(2 \times 40 \mathrm{~cm})$ which had previously been equilibrated with $1 \%$ formic acid. The protein was eluted with $1 \%$ formic acid and the fractions containing the protein were pooled and lyophilized. It was then dissolved in $1 \mathrm{ml}$ of $1 \%$ formic acid and $6 \mathrm{M}$ urea and applied to a Sephadex G-75 column $(1.6 \times 84 \mathrm{~cm})$ which had previously been equilibrated with $1 \%$ formic acid and $6.0 \mathrm{M}$ urea. The flow rate was $0.1 \mathrm{ml} / \mathrm{min}$. The peaks containing the activation peptide and Factor $\mathrm{IX}_{\mathrm{a}}$ were pooled separately and lyophilized. Factor $\mathrm{IX}_{\mathrm{a}}$ was then reduced and carboxymethylated or pyridylethylated by the methods of Crestfield et al. (23) or Friedman et al. (24). The heavy and 
light chains were applied to a Sephadex G-50 superfine column $(1.6 \times 85 \mathrm{~cm})$ which had previously been equilibrated with $1 \%$ formic acid and $6.0 \mathrm{M}$ urea, and the column was eluted with the same solution. The flow rate was $0.2 \mathrm{ml} / \mathrm{min}$. The peak containing the heavy chain was desalted on a Sephadex G-25 column $(2 \times 40 \mathrm{~cm})$ in $10 \%$ formic acid and lyophilized. The peak containing the light chain was also desalted, lyophilized, and then redissolved in $6 \mathrm{M}$ urea and $1 \%$ formic acid. It was then subjected to gel filtration on a second Sephadex G-50 column under the same conditions to free it from small amounts of contaminating heavy chain. After the second passage over the Sephadex G-50 column, the pure light chain was desalted and lyophilized.

The digestion of the heavy chain of Factor $\mathrm{IX}_{\mathrm{a}}$ by cyanogen bromide was performed by dissolving $9 \mathrm{mg}$ of salt-free Spyridylethyl Factor $\mathrm{IX}_{\mathrm{a}}$ heavy chain in $1.5 \mathrm{ml}$ of $70 \%$ formic acid. Cyanogen bromide $(45 \mathrm{mg}$ ) was then added and the reaction was allowed to proceed for $36 \mathrm{~h}$ at $4^{\circ} \mathrm{C}$. After lyophilization, the digest was fractionated by gel filtration on a Sephadex G-50 superfine column $(2.6 \times 95 \mathrm{~cm})$ in $10 \%$ formic acid at a flow rate of $0.30 \mathrm{ml} / \mathrm{min}$.

Amino terminal sequence analyses were performed with a Beckman sequenator model 890C (Beckman Instruments, Inc., Fullerton, Calif.) described (32-34). For amino terminal analyses, the approximate amounts of samples that were used were $1.0 \mathrm{mg}$ of the activation peptide, $1.5 \mathrm{mg}$ of the $\mathrm{S}$ carboxymethyl light chain of Factor $\mathrm{IX}_{\mathrm{a}}, 0.9 \mathrm{mg}$ of the Spyridylethyl cyanogen bromide peptide containing the active site of Factor $\mathrm{IX}_{\mathrm{a}}, 1.5 \mathrm{mg}$ of the $\mathrm{S}$-pyridylethyl heavy chain of Factor IX $\mathrm{I}_{\mathrm{a}}$, and $0.8 \mathrm{mg}$ of the third cyanogen bromide fragment from the digest of the heavy chain of Factor IX $\mathrm{I}_{\mathrm{a}}$. All analyses were performed twice. In the quantitation of the amino terminal residues, protein concentration was determined by amino acid analysis after hydrolysis of the sample in $6 \mathrm{~N} \mathrm{HCl}$. Norleucine was employed as the internal standard to calculate protein recovery.

Carboxyl terminal analysis was carried out by a modification of the procedure of Fraenkel-Conrat et al. (35). Pancreatic carboxypeptidases A and B were treated with $1 \mathrm{mM}$ DFP before use. The activation peptide $(\cong 0.5 \mathrm{mg})$ and the $\mathrm{S}$ carboxymethylated light chain $(\cong 1.0 \mathrm{mg})$ were dissolved in 0.2 $\mathrm{ml}$ and $0.5 \mathrm{ml}$, respectively, of $0.01 \mathrm{M}$ sodium phosphate buffer, $\mathrm{pH} 8.0$, containing $1.0 \%$ sodium dodecyl sulfate. The samples were boiled for $10 \mathrm{~min}$ and diluted by the addition of $0.25 \mathrm{ml}$ or $0.5 \mathrm{ml}$ of $0.01 \mathrm{M}$ sodium phosphate buffer, $\mathrm{pH} 8.0$, for the activation peptide and the S-carboxymethylated light chain, respectively. Half of the sample was incubated for $16 \mathrm{~h}$ at $37^{\circ} \mathrm{C}$ with carboxypeptidase $\mathrm{A}$ and the other half with carboxypeptidase B employing an enzyme-to-substrate weight ratio of 1:50. The liberated amino acids were then analyzed in the amino acid analyzer. The amount of the peptides was quantitated by amino acid analysis of a 24-h hydrolysate employing norleucine as an internal standard.

Antibodies against human Factor IX were prepared from rabbits which had been injected subcutaneously three times with $0.5-0.7 \mathrm{mg}$ of purified human Factor IX with Freund's complete or incomplete adjuvant. The animals were bled by heart puncture and the antibodies were purified as described by Fujikawa et al. (36). Immunoelectrophoresis was performed on glass slides $(2.5 \times 7.5 \mathrm{~cm})$ with $1 \%$ agarose in $0.05 \mathrm{M}$ sodium barbital buffer, $\mathrm{pH} 8.6$, containing $0.01 \%$ sodium azide according to the method of Scheidegger (37). Samples $(4-7 \mu \mathrm{g})$ were subjected to electrophoresis for 50 $\min$ at $150 \mathrm{~V}$ at $4^{\circ} \mathrm{C}$ and $50 \mu \mathrm{l}$ of antibody solution $(2.0$ $\mathrm{mg} / \mathrm{ml}$ ) was added to the trough and allowed to diffuse through the agarose gel overnight.

Inhibition of human Factor $I X_{a \beta}$ by human antithrombin III. The inhibition of human Factor $\mathbf{I X}_{a \beta}$ was carried out by incubating human antithrombin III $(0.3 \mathrm{mg})$ with Factor IX $_{\mathrm{a} \beta}$ $(0.12 \mathrm{mg})$ in $1 \mathrm{ml}$ of $0.02 \mathrm{M}$ imidazole-HCl buffer, $\mathrm{pH} \mathrm{7.4,}$ containing $0.15 \mathrm{M} \mathrm{NaCl}$ in the presence or absence of heparin $(10 \mathrm{U})$. Samples were incubated at $37^{\circ} \mathrm{C}$ and $10-\mu$ l aliquots were withdrawn at various times, diluted with ice-cold Michaelis buffer, and assayed immediately for coagulant activity as previously described. The inhibition of Factor IX $_{\mathrm{a} \beta}$ was also studied as a function of antithrombin III concentration. In these experiments, $10 \mu \mathrm{M}$ of Factor IX

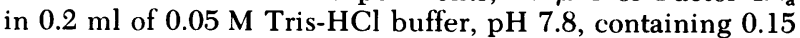
$\mathrm{M} \mathrm{NaCl}$, in the presence or absence of $10 \mathrm{U} / \mathrm{ml}$ of heparin, was incubated with increasing concentrations of antithrombin III at $37^{\circ} \mathrm{C}$ for $15 \mathrm{~min}$ (in the presence of heparin) or $2 \mathrm{~h}$ (in the absence of heparin). The residual Factor $\mathbf{I X}_{\mathrm{a} \beta}$ activity was then assayed for coagulant and esterase activity as previously described.

\section{RESULTS}

Activation of human Factor IX by Factor $X_{a}$. A time-course for the activation of Factor IX by Factor $\mathrm{XI}_{\mathrm{a}}$ is shown in Fig. 1. A small activation of Factor IX by Factor $\mathrm{XI}_{\mathrm{a}}$ occurred in the absence of calcium. Activated Factor IX formed in this reaction was called Factor IX $\mathrm{X}_{\mathrm{a} \beta}$ analogous to the bovine system described (11). Factor $\mathrm{IX}_{\mathrm{a} \beta}$, generated by the action of Factor $\mathrm{XI}_{\mathrm{a}}$, gave a clotting time of $55 \mathrm{~s}$ at a final concentration of $250 \mathrm{ng} / \mathrm{ml}$ in the coagulant assay (see Methods). Factor

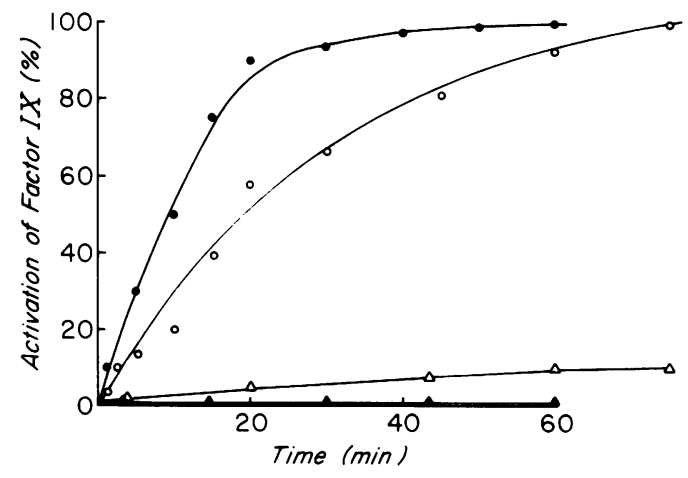

FIGURE 1 Time-course for the activation of human Factor IX by human Factor $\mathrm{XI}_{\mathrm{a}}$ and by RVV-X. The activation by Factor $\mathrm{XI}_{\mathrm{a}}$ was performed by adding Factor $\mathrm{XI}_{\mathrm{a}}(0.015 \mathrm{mg})$ to a reaction mixture containing $1.2 \mathrm{mg}$ of human Factor IX in 1.2 $\mathrm{ml}$ of $0.05 \mathrm{M}$ Tris- $\mathrm{HCl}$ buffer ( $\mathrm{pH} 7.8$ ), $0.15 \mathrm{M} \mathrm{NaCl}$ and $5 \mathrm{mM}$ $\mathrm{CaCl}_{2}$. At the appropriate time intervals, aliquots $(5 \mu \mathrm{l})$ were withdrawn and assayed for coagulant activity as described in Methods. The activation of Factor IX by RVV-X was performed by the addition of $0.02 \mathrm{ml}$ of $\mathrm{RVV}$-X-Sepharose to each of a series of small plastic centrifuge tubes containing human Factor IX $(0.8 \mathrm{mg} / \mathrm{ml})$ in $0.07 \mathrm{ml}$ of $0.05 \mathrm{M}$ Tris- $\mathrm{HCl}$ buffer $(\mathrm{pH}$ $7.8), 0.15 \mathrm{M} \mathrm{NaCl}$, and $10 \mathrm{mM} \mathrm{CaCl}$. After incubation for various times, the reactions were terminated by the addition of $0.01 \mathrm{ml}$ of $0.2 \mathrm{M}$ EDTA. Activated Factor IX was separated from the RVV-X-Sepharose by brief centrifugation, and Factor $\mathrm{IX}_{\mathrm{a}}$ coagulant activity was then assayed as described in Methods. (O), Factor IX plus Factor $\mathrm{XI}_{\mathrm{a}}$ in the presence of $\mathrm{CaCl}_{2} ;(\triangle)$, Factor IX plus Factor $\mathbf{X I}_{\mathrm{a}}$ in the absence of $\mathrm{CaCl}_{2} ;(-), F$ actor IX plus RVV-X in the presence of $\mathrm{CaCl}_{2}$; $(\Delta)$, Factor IX plus RVV-X in the absence of $\mathrm{CaCl}_{2}$. 
$\mathrm{IX}_{\mathrm{a} \beta}$ also had esterase activity and hydrolyzed 0.33 $\mu \mathrm{mol}$ of ${ }_{L}\left[{ }^{3} \mathrm{H}\right]$ tosyl arginine methyl ester per hour per milligram of enzyme at room temperature. The substrate concentration was $0.16 \mathrm{mM}$.

A difference in electrophoretic properties of Factor IX and Factor IX $\mathrm{X}_{\mathrm{a} \beta}$ was apparent when the two proteins were examined by immunoelectrophoresis (Fig. 2). Factox IX (sample 1) had a faster electrophoretic mobility than Factor $\mathrm{IX}_{\mathrm{a} \beta}$ (sample 2). Both proteins formed single, sharp precipitin lines.

A change in Factor IX during the activation by Factor $\mathrm{XI}_{\mathrm{a}}$ was also observed by sodium dodecyl sulfate-polyacrylamide gel electrophoresis (Fig. 3). In these experiments, aliquots were removed at various times from an activation reaction corresponding to those shown in Fig. 1 and analyzed by gel electrophoresis before reduction (upper panel) and after reduction (lower panel). At zero time, Factor IX $\cong$ mol wt 57,000 ) appeared as a single-chain species (upper

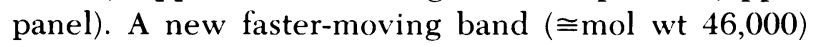
was observed during the activation reaction and the appearance of this band occurred in parallel with the increase in coagulant activity. In reduced gels (lower panel), three new bands were observed. The fastest band ( $\cong$ mol wt 18,000$)$ stained rather poorly and corresponded to the light chain of Factor IX $\mathrm{X}_{\mathrm{a}}$. The second fastest band ( $\cong$ mol wt 28,000) stained strongly and corresponded to the heavy chain of Factor $I_{\mathrm{X}}$. The appearance of this band occurred in parallel with the increase of coagulant activity. The third fastest band $(\cong$ mol wt 45,000$)$ appeared within the first $5 \mathrm{~min}$ of the reaction and remained fairly constant during the next $40 \mathrm{~min}$. This band then disappeared as the reaction went to completion. These data suggest that human Factor IX is activated via a two-step mechanism analogous to that of bovine Factor IX. In this latter reaction, a two-chain intermediate is initially formed. This intermediate lacks enzymatic activity and con-

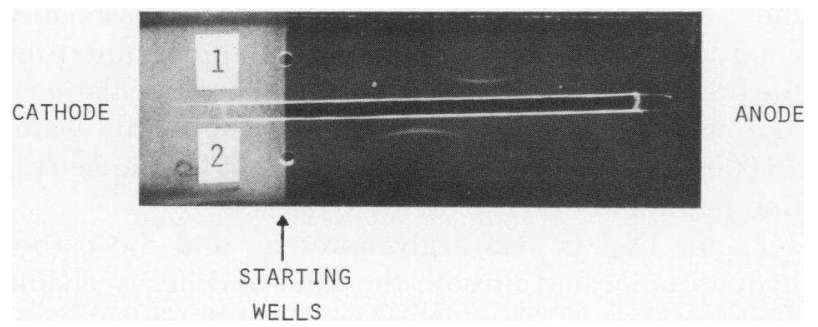

FIGURE 2 Immunoelectrophoresis of human Factor IX and Factor IX $\mathrm{X}_{\mathrm{a} \beta}$. Factor IX ( $5 \mu$ l containing $5 \mu \mathrm{g}$ of protein) was placed in well no. 1 , and Factor $\operatorname{IX}_{\mathrm{a} \beta}(5 \mu \mathrm{l}$ containing $4 \mu \mathrm{g}$ of protein) was placed in well no. 2. Electrophoresis was carried out in $0.05 \mathrm{M}$ sodium barbital buffer, $\mathrm{pH} 8.6$, at $1.50 \mathrm{~V}$ for $50 \mathrm{~min}$ at $4^{\circ} \mathrm{C}$. After electrophoresis, $0.05 \mathrm{ml}$ of rabbit antibody solution $(2.0 \mathrm{mg} / \mathrm{ml})$ against human Factor IX was placed in the center trough. After $24 \mathrm{~h}$, precipitin lines appeared and the slides were then photographed.
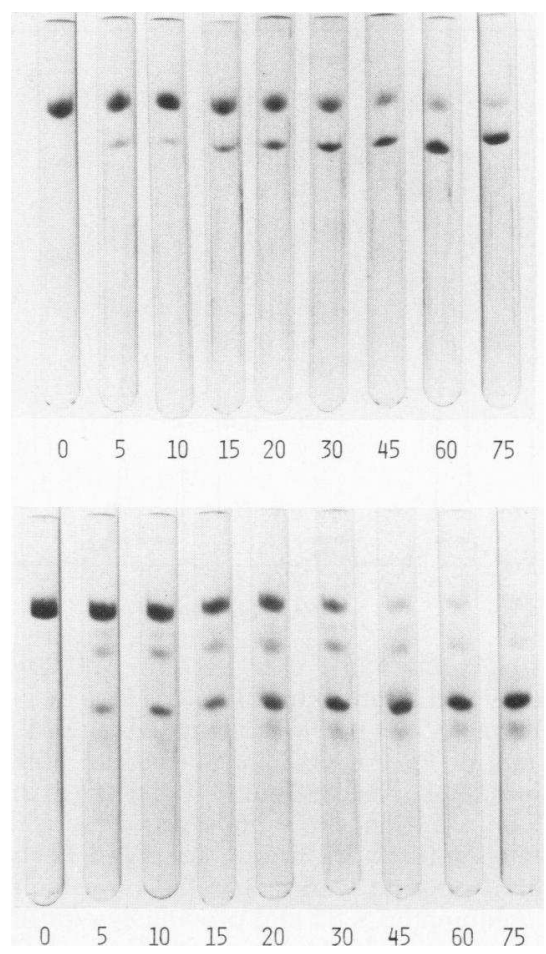

Figure 3 Sodium dodecyl sulfate-polyacrylamide gel electrophoresis pattern of Factor IX activated by Factor $\mathrm{XI}_{\mathrm{a}}$. Samples (containing $\cong 30 \mu \mathrm{g}$ of protein) were removed at various times from an incubation mixture corresponding to those shown in Fig. 1, and subjected to electrophoresis on $8.5 \%$ polyacrylamide gels as described in Methods. The numbers under the gels refer to the incubation time in minutes. The anode was at the bottom of the gels. The top panel shows the unreduced samples, whereas the bottom panel shows the reduced samples.

tains a heavy chain and a light chain held together by a disulfide bond(s). In a second step, an activation peptide is split from the amino terminal end of the heavy chain of the intermediate giving rise to Factor $\mathrm{IX}_{\mathrm{a} \beta}$ and an activation peptide. This reduces the molecular weight of the precursor by $\cong 11,000$. The data shown in Fig. 3 suggest that the mechanism of activation of human Factor IX is essentially identical to that of bovine Factor IX. Proof of this mechanism for the human protein, however, required the isolation and characterization of the various polypeptide chains.

Isolation of the heavy and light chains of human Factor IX $X_{a \beta}$ and the activation peptide. Factor IX (10 $\mathrm{mg}$ ) was activated in the presence of Factor $\mathrm{XI}_{\mathbf{a}}$ for 120 min under conditions similar to those shown in Fig. 1. The reaction mixture was then fractionated on a Sephadex G-75 superfine column in $6.0 \mathrm{M}$ urea containing $1 \%$ formic acid (Fig. 4, left panel). The major protein peak, containing Factor $\mathrm{IX}_{\mathrm{a} \beta}$, eluted in front of a small protein peak which was tentatively identified as the activation peptide. The latter peak migrated as a single band on sodium dodecyl sulfate- 


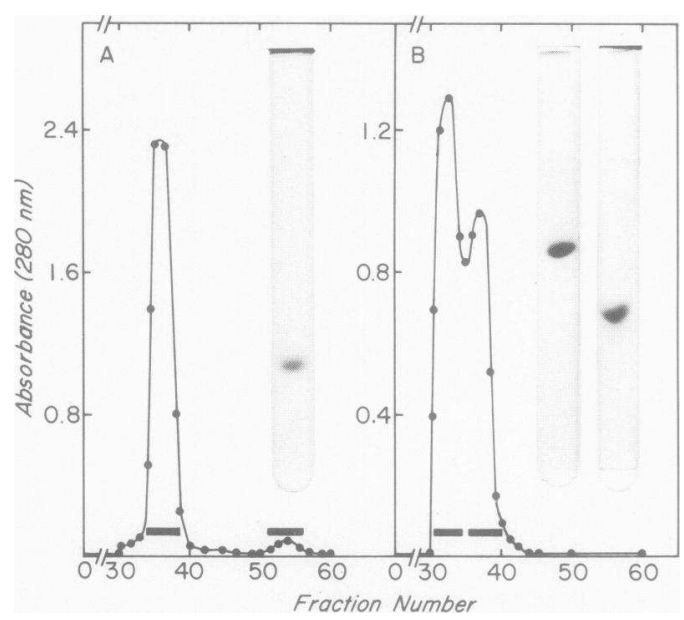

FIgURE 4 Separation of Factor $\mathrm{IX}_{\mathrm{a} \beta}$, the activation peptide, and the heavy and light chains of Factor $\mathrm{IX}_{\mathrm{a} \beta}$ by gel filtration. Human Factor IX (10 mg) was activated at $37^{\circ} \mathrm{C}$ for $75 \mathrm{~min}$ with $0.15 \mathrm{mg}$ of Factor $\mathrm{XI}_{\mathrm{a}}$ as described in Methods. After desalting on a Sephadex G-25 column $(2 \times 40 \mathrm{~cm})$ in $1 \%$ formic acid and lyophilization, the sample was dissolved in $1 \mathrm{ml}$ of 6.0 $\mathrm{M}$ urea containing $1 \%$ formic acid, and Factor $\mathrm{IX}_{\mathrm{a} \beta}$ and the activation peptide were separated on a Sephadex G-75 superfine column $(1.6 \times 85 \mathrm{~cm})$ previously equilibrated with 6.0 M urea containing $1 \%$ formic acid (left panel). The column was then eluted with $6.0 \mathrm{M}$ urea containing $1 \%$ formic acid. The flow rate was $0.1 \mathrm{ml} / \mathrm{min}$, and $1.7 \mathrm{ml}$ fractions were collected. Factor $\mathrm{IX}_{\mathrm{a} \beta}$ and the activation peptide were pooled as shown by the bars, desalted, and lyophilized. Factor IX $_{\mathrm{a} \beta}$ was then reduced, pyridylethylated (or carboxymethylated), and fractionated on a Sephadex G-50 superfine column $(1.6 \times 85$ $\mathrm{cm})$ previously equilibrated with $6.0 \mathrm{M}$ urea containing $1 \%$ formic acid (right panel). The column was then eluted with 6.0 M urea containing $1 \%$ formic acid. The flow rate was 0.2 $\mathrm{ml} / \mathrm{min}$ and $1.7 \mathrm{ml}$ fractions were collected. The peaks containing the heavy and light chains were pooled (as indicated by the bars), desalted and lyophilized. The light chain was further purified from small amounts of contaminating heavy chain by a second passage over the Sephadex G-50 superfine column under the same conditions. The sodium dodecyl sulfate-polyacrylamide gel of the activation peptide $(20 \mu \mathrm{g})$ is shown in the insert in the left panel, and the gels for the Spyridylethyl heavy chain $(10 \mu \mathrm{g})$ and the S-pyridylethyl light chain $(10 \mu \mathrm{g})$ are shown in the insert in the right panel. The gels $(9.5 \%)$ were run for $3.5 \mathrm{~h}$ and stained with Coomassie Brilliant Blue as described in Methods. The anode was at the bottom of the gels.

polyacrylamide gels with $\cong$ mol wt 11,000 (Fig. 4 , insert, left panel). The first peak containing Factor $\mathrm{IX}_{\mathrm{a} \beta}$ was then reduced, carboxymethylated (or pyridylethylated), and the chains were separated on a Sephadex G-50 superfine column (Fig. 4, right panel). The heavy chain of Factor $\mathrm{IX}_{\mathrm{a} \beta}$ appeared in the first peak, and the light chain appeared in the second peak. These protein peaks also migrated as single bands on sodium dodecyl sulfate-polyacrylamide gel electrophoresis (Fig. 4, insert, right panel). The heavy chain (apparent mol wt 28,000) is shown in the left gel, and the light chain (apparent mol wt 18,000) is shown in the right gel.

Amino terminal analyses. To identify the origin of the chains of Factor $\mathrm{IX}_{\mathrm{a} \beta}$ and the bonds cleaved during the activation reaction, it was necessary to examine the amino terminal sequences of the heavy and light chains of Factor $\mathrm{IX}_{\mathrm{a} \beta}$ and the activation peptide. The amino terminal sequences and the equivalents at each cycle for these various polypeptides are shown in Table I. Amino acids that are underlined are identical to those found in bovine Factor IX (38). The amino terminal sequence of the light chain was found to be Tyr-Asn-Ser-Gly-Lys-Leu. This sequence is identical to that found in the precursor molecule (7). These data indicate that the amino terminal portion of Factor IX gives rise to the light chain of Factor $\mathrm{IX}_{\mathrm{a} \beta}$. The amino acid sequence of the activation peptide was found to be Ala-Glu-Thr-Val-Phe-ProAsp-Val-Asp-Tyr-Val. This sequence is homologous to that found for the heavy chain of bovine Factor IX intermediate as well as the activation peptide liberated in the formation of bovine Factor $\operatorname{IX}_{\mathrm{a} \beta}$ (10). The amino acid sequence for the first 18 residues of the heavy chain of human Factor IX $_{\mathrm{a} \beta}$ was also determined. The first seven residues were Val-Val-GlyGly-Glu-Asp-Ala and this sequence is identical to that found in bovine Factor $\operatorname{IX}_{\mathrm{a} \beta}(10)$. These data strongly support the conclusion that human Factor IX is activated by Factor $\mathrm{XI}_{\mathrm{a}}$ by a two-step mechanism analogous to bovine Factor IX.

Composition of the heavy and light chains of human Factor $I X_{a \beta}$ and the activation peptide. The amino acid and carbohydrate compositions of the two chains of Factor $\mathrm{IX}_{\mathrm{a} \beta}$ and the activation peptide are shown in Table II. A summation of the amino acid and carbohydrate residues in the light chain (column 1) and the heavy chain (column 2) gives the composition for Factor $\mathrm{IX}_{\mathrm{a} \beta}$ (column 3). Also, a summation of the composition of the light chain, the heavy chain, and the activation peptide (column 5) is in reasonably good agreement with that previously determined for the precursor protein (column 6). In these calculations, mol wt 18,000 was employed for the light chain, 28,000 for the heavy chain, and 11,100 for the activation peptide.

Factor $\mathrm{IX}_{\mathrm{a} \beta}$ is also a glycoprotein, and the carbohydrate is located in both the light and heavy chains of the molecule. The activation peptide which is released during the activation reaction is particularly rich in hexose, hexosamine, and neuraminic acid and contains $50 \%$ carbohydrate.

Effects of carboxypeptidases $A$ and $B$ on the activation peptide and the light chain of Factor $I X_{a \beta}$. To further characterize the peptide bonds split during the activation reaction, the activation peptide and the light chain of Factor $\mathrm{IX}_{\mathrm{a} \beta}$ were treated with carboxypeptidase 
TABLE I

Amino Terminal Secuences of the Heavy and Light Chains, Activation Peptide, and Cyanogen Bromide Fragments of Human Factor IX*

\begin{tabular}{|c|c|c|c|c|c|c|c|c|c|c|c|c|c|c|c|c|c|c|c|c|c|c|}
\hline Residue & 1 & 2 & 3 & 4 & 5 & 6 & 7 & 8 & () & 10 & 11 & 12 & 13 & 14 & 15 & 16 & 17 & 18 & 19 & 20 & 21 & 22 \\
\hline Light chain & $T y r$ & Asn & Ser & Gly & $L ! ! s$ & Le'u & (Gla) & (Gla) & Phe & & & & & & & & & & & & & \\
\hline Equivalents & 0.5 & 0.2 & N.Q. & 0.2 & 0.3 & 0.4 & - & - & 0.2 & & & & & & & & & & & & & \\
\hline \multicolumn{23}{|l|}{ Heavy chain } \\
\hline Equivalents & 0.4 & 0.7 & 0.4 & 0.3 & 0.5 & 0.5 & 0.5 & 0.3 & 0.2 & 0.4 & 0.2 & 0.3 & 0.1 & N.Q. & 0.1 & 0.3 & 0.3 & 0.3 & & & & \\
\hline \multicolumn{22}{|l|}{ Activation } & \\
\hline Equivalents & 0.5 & 0.4 & N.Q. & 0.6 & 0.5 & N.Q. & 0.2 & 0.5 & 0.2 & 0.3 & 0.3 & & & & & & & & & & & \\
\hline CBR II & Phe' & Cyss & Ala & Gly & Phe & His & Glu & Gly & Gly & Arg & Asp & $S^{\prime} r$ & Ciys & $G l n$ & Gly & Asp & SER & Gly & Gly & $\operatorname{Pro}$ & (His) & Val \\
\hline Equivalents & 0.6 & 0.9 & 0.3 & 0.8 & 0.3 & N.Q. & 0.1 & 0.7 & 0.6 & N.Q. & 0.2 & N.Q. & 0.4 & 0.1 & 0.2 & 0.1 & N.(.). & 0.1 & 0.1 & N.(). & - & 0.1 \\
\hline CBR III & Lyys & $G l !$ & $L ! y s$ & $T y, r$ & Gl! & Ile & $T y r$ & Thr & $L y / s$ & Val & $S_{c \prime r}$ & Arg & $T y r$ & Val & Asn & & & & & & & \\
\hline Equivalents & 0.4 & 0.6 & 0.4 & 0.7 & 0.5 & 0.4 & 0.5 & N.Q. & 0.2 & 0.3 & N.Q. & N.Q. & 0.3 & 0.2 & 0.1 & & & & & & & \\
\hline
\end{tabular}

* Residues that are italicized are identical to bovine Factor IX (38); -, not determined; N.Q., not (quantitated; ( ), tentative identification; the active site serine is shown in capital lettrs. Yields for the various residues were calculated by employing the following molecular weights: light chain, 18,0 oo; heary chain, 28,000; CBR I, 18,000; activation peptide, 11,000; CBR II, 5,000; CBR III, 3,000. CBR, cyanogen bromide.

A or carboxypeptidase B to identify the carboxyl terminal amino acid. Arginine (1.0 equivalent) was released from the light chain of Factor $\mathrm{IX}_{\mathrm{a} \beta}$ after incubation with carboxypeptidase $\mathrm{B}$ for $16 \mathrm{~h}$ at $37^{\circ} \mathrm{C}$ in $0.05 \%$ sodium dodecyl sulfate. No other amino acids were found. Under these same conditions, arginine (0.7 equivalents) was released from the activation peptide by carboxypeptidase $\mathrm{B}$. No other amino acids were found. Furthermore, no amino acids were released from either polypeptide by carboxypeptidase A. These data indicate that arginine is the carboxyl terminal amino acid of the activation peptide as well as the light chain of Factor $\mathrm{IX}_{\mathrm{a} \beta}$. These experiments also indicate that a specific arginyl-alanine peptide bond and a specific arginyl-valine peptide bond are cleaved in Factor IX during the conversion of the precursor to Factor IX $\mathrm{X}_{\mathrm{a} \beta}$.

Amino acid sequence of the active site. To determine the amino acid sequence in the active site region of human Factor IX, the S-pyridylethyl heavy chain of Factor $\mathrm{IX}_{\mathrm{a} \beta}(9 \mathrm{mg})$ was subjected to cyanogen bromide digestion as described in Methods. The cyanogen bromide fragments were then fractionated on a Sephadex G-50 superfine column $(2.5 \times 95 \mathrm{~cm})$ in $10 \%$ formic acid (Fig. 5).Three major peaks were observed, which is consistent with the presence of two methionine residues in the heavy chain of the molecule (Table II). The first peak showed a shoulder on the leading edge of the peak, and this was found to be because of residual undigested heavy chain. Accordingly, the trailing edge of this peak and the remaining two peaks were pooled separately and lyophilized. The peptides recovered from peaks I, II, and III migrated as single bands on sodium dodecyl sulfate-polyacrylamide gel electrophoresis with $\cong$ mol wt 18,000, 5,000, and 3,000, respectively. The amino terminal sequences of the three peptides and the equivalents at each cycle are shown in Table I. The residues that are underlined are identical to residues from the corresponding region in bovine Factor IX (38). The first cyanogen bromide fragment had an amino terminal sequence which was the same as that of the heavy chain of human Factor $\mathrm{IX}_{\mathrm{a} \beta}$. The second cyanogen bromide fragment contained the active site sequence of Factor $\mathrm{IX}_{\mathrm{a} \beta}$. The active site serine residue appeared in position 17 of this peptide. The third cyanogen bromide fragment contained an amino terminal lysine, and the sequence of this peptide is homologous to a sequence in bovine Factor IX $\mathrm{X}_{\mathrm{a} \beta}$ which is located in the carboxyl terminal region of the heavy chain of the molecule (38).

Effect of DFP and antithrombin III on human Factor $I X_{a \beta}$. The coagulant activity of Factor $I_{\mathrm{a} \beta}$ was not affected by incubation of the enzyme with $0.005 \mathrm{M}$ $\mathrm{DFP}$ for $60 \mathrm{~min}$ at $37^{\circ} \mathrm{C}$ at $\mathrm{pH}$ 7.8. Factor $\mathrm{IX}_{\mathrm{a} \beta}$ was inhibited by antithrombin III, however, and the rate of inactivation was extremely rapid in the presence of heparin. Similar results have been published for human and bovine Factor $\operatorname{IX}_{\mathrm{a} \beta}(5,31)$. The inhibition of Factor IX $\mathrm{X}_{\mathrm{a} \beta}$ as a function of antithrombin III concentration also gave results that were essentially identical to the bovine system (31). In the presence or absence of heparin, a one-to-one molar complex of enzyme and inhibitor was found at the inhibitor concentration giving maximal inhibition.

The formation of a stable one-to-one molar complex between human Factor IX $\mathrm{X}_{\mathrm{a} \beta}$ and antithrombin III was demonstrated by sodium dodecyl sulfate-polyacrylamide gel electrophoresis (Fig. 6). Gels 1 and 4 show antithrombin III before and after reduction of the disulfide bonds. Gels 2 and 5 show Factor IX $_{\mathrm{a} \beta}$ before and after reduction. Gel 3 shows a mixture containing Factor $\mathrm{IX}_{\mathrm{a} \beta}$ and antithrombin III (twofold molar excess) in- 
TABLE II

Amino Acid and Carbohydrate Compositions of Human Factor IX

\begin{tabular}{|c|c|c|c|c|c|c|}
\hline Components & $\begin{array}{l}\text { Light chain of } \\
\text { Fictor } I_{\alpha \beta}\end{array}$ & $\begin{array}{l}\text { Heavy chain of } \\
\text { Factor IX } \mathrm{X}_{\alpha \mu \beta}\end{array}$ & $\begin{array}{l}\text { Heavy plus light } \\
\text { chains of } \\
\text { Factor IX } \mathrm{I}_{\mathrm{aB}}\end{array}$ & $\begin{array}{c}\text { Activation } \\
\text { peptide }\end{array}$ & $\begin{array}{l}\text { Heavy plus light } \\
\text { chains plus } \\
\text { activation } \\
\text { peptide }\end{array}$ & Factor IX \\
\hline & 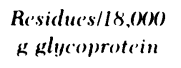 & $\begin{array}{l}\text { Ressiducs } / 28,(X) \\
\text { g gly/coprotein }\end{array}$ & $\begin{array}{l}\text { Residues/46,o(N) } \\
\text { g glycoprotein }\end{array}$ & $\begin{array}{l}\text { Residues/l1, } l(0) \\
\text { g glycoprotein }\end{array}$ & $\begin{array}{l}\text { Residuess } 157,(0) \\
\text { g glycoprotein }\end{array}$ & $\begin{array}{l}\text { Residues } / 57,20()) \\
\text { g glycoprotein }\end{array}$ \\
\hline \multicolumn{7}{|l|}{ Amino acid } \\
\hline Lysine & 9.9 & 14.2 & 24.1 & 0.9 & 25.0 & 26.6 \\
\hline Histidine & 0.4 & 6.8 & 7.2 & 0.3 & 7.5 & 8.8 \\
\hline Arginine & 5.8 & 8.2 & 14.0 & 1.3 & 15.3 & 17.3 \\
\hline Aspartic acid & 19.7 & 22.8 & 42.5 & 8.2 & 50.7 & 45.9 \\
\hline Threonine & 7.0 & 15.2 & 22.2 & 7.0 & 29.2 & 29.4 \\
\hline Serine & 10.5 & 11.7 & 22.2 & 3.6 & 25.8 & 26.6 \\
\hline Glutamic acid & 24.4 & 23.0 & 47.4 & 7.0 & 54.4 & 47.0 \\
\hline Proline & 6.3 & 8.2 & 14.5 & 1.6 & 16.1 & 14.9 \\
\hline Glycine & 11.6 & 23.9 & 35.5 & 1.8 & 37.3 & 34.1 \\
\hline Alanine & 4.7 & 12.1 & 16.8 & 2.8 & 19.6 & 22.3 \\
\hline Half-cystine & 15.1 & 8.6 & 23.7 & 0.6 & 24.3 & 19.6 \\
\hline Valine & 10.1 & 20.7 & 30.8 & 4.1 & 34.9 & 33.0 \\
\hline Methionine & 0.9 & 1.9 & 2.8 & () & 2.8 & 2.4 \\
\hline Isoleucine & 2.7 & 13.4 & 16.1 & 2.6 & 18.7 & 22.3 \\
\hline Leucine & 5.8 & 13.0 & 18.8 & 1.8 & 20.6 & 2.5 .4 \\
\hline Tyrosine & 4.0 & 8.2 & 12.2 & 1.4 & 13.6 & 14.0 \\
\hline Phenylalanine & 8.6 & 8.9 & 17.5 & 3.9 & 21.4 & 21.5 \\
\hline Tryptophan & 4.9 & 7.0 & 11.9 & () & 11.9 & 11.7 \\
\hline $\begin{array}{l}\text { Molecular weight* } \\
\text { (protein) }\end{array}$ & 16,700 & 25,300 & 42,000 & $5,500)$ & 47,700 & 47,500 \\
\hline \multicolumn{7}{|l|}{ Carbohydrate $\ddagger$} \\
\hline Hexose & 2.0 & 6.2 & 8.2 & 7.9 & 16.1 & 16.2 \\
\hline Hexosamine & 2.0 & 4.3 & 6.3 & 8.3 & 14.6 & 18.1 \\
\hline Neuraminic acid & 1.8 & 2.2 & 4.0 & 7.9 & 11.9 & 10.0 \\
\hline $\begin{array}{l}\text { Molecular weight } \\
\text { (carbohydrate) }\end{array}$ & 1,300 & 2,700 & 4,000 & 5,600 & 9,600 & 9,700 \\
\hline $\begin{array}{l}\text { Molecular weight } \\
\text { (glycoprotein) }\end{array}$ & 18,000 & 28,000 & 46,000 & 11,100 & 57,000 & 57,200 \\
\hline Carbohydrate, \% & 7 & 10 & 9 & 50 & 17 & 17 \\
\hline Protein, \% & 93 & 90 & 91 & 50 & 83 & 83 \\
\hline
\end{tabular}

* Molecular weights were rounded off to the nearest 100 .

† Carbohydrate was expressed as $\mathrm{N}$-acetylhexosamine and $\mathrm{N}$-acetylneuraminic acid.

cubated for $10 \mathrm{~min}$ in the presence of heparin. Two protein bands were observed in this gel. The fast-moving protein band corresponds to residual antithrombin III. The band corresponding to Factor $\mathrm{IX}_{\mathrm{a} \beta}$ has disappeared, but a new slow-moving band is present and this band corresponds to an enzyme inhibitor complex with $\cong$ mol wt 90,000. When the mixture containing the complex of enzyme and inhibitor was reduced, three major bands were observed (gel 6). The fast-moving band corresponds to the light chain of Factor $I_{X_{a}}$. The second fastest-moving band corresponds to residual antithrombin III. The slowest-moving band corresponds to a complex of antithrombin III and the heavy chain of Factor IX $\mathrm{X}_{\mathrm{a} \beta}$. Little or no free heavy chain of Factor $\mathrm{IX}_{\mathrm{a} \beta}$ was present in this gel. These data indicate that a very stable one-to-one molar complex is formed between Factor $\mathrm{IX}_{\mathrm{a} \beta}$ and antithrombin III, and this complex directly involves the heavy chain of Factor IX $_{a \beta}$ which contains the active site serine residue.

Activation of human Factor IX by a protease from $R V V-X$. A time-course for the activation of Factor IX by RVV-X-Sepharose is shown in Fig. 1 (solid circles). Under the conditions employed, the reaction was essentially complete after $20-30 \mathrm{~min}$ of incubation. The 


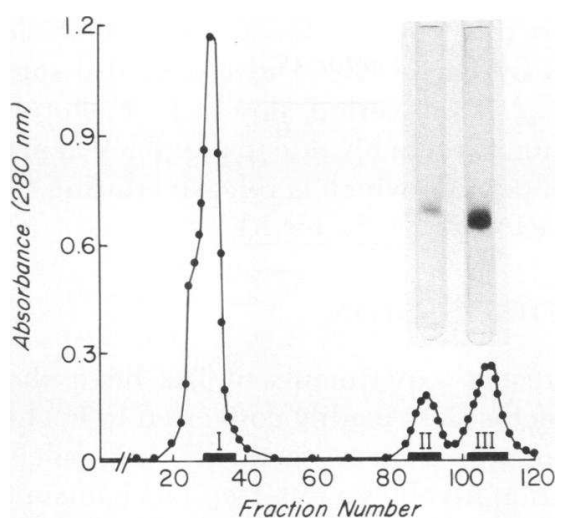

Figure 5 Gel filtration of the cyanogen bromide peptides from the S-pyridylethyl heavy chain of human Factor IX $\mathrm{X}_{\mathrm{a} \beta}$. The digest $(9 \mathrm{mg}$ ) was dissolved in $2 \mathrm{ml}$ of $25 \%$ formic acid and applied to a Sephadex G-50 superfine column $(2.6 \times 95$ $\mathrm{cm})$, which had been previously equilibrated with $10 \%$ formic acid. The column was eluted with $10 \%$ formic acid at a flow rate of $0.3 \mathrm{ml} / \mathrm{min}$, and $2.0 \mathrm{ml}$ fractions were collected. The various peaks, as shown by the bars, were pooled individually, and the peptides were lyophilized. The sodium dodecyl sulfate-polyacrylamide gels of the second and third cyanogen bromide peptides are shown above their respective elution positions. The samples ( $\cong 10 \mu \mathrm{g}$ ) were run on $10 \%$ gels for $4 \mathrm{~h}$ and stained with Coomassie Brilliant Blue. The anode was at the bottom of the gels.

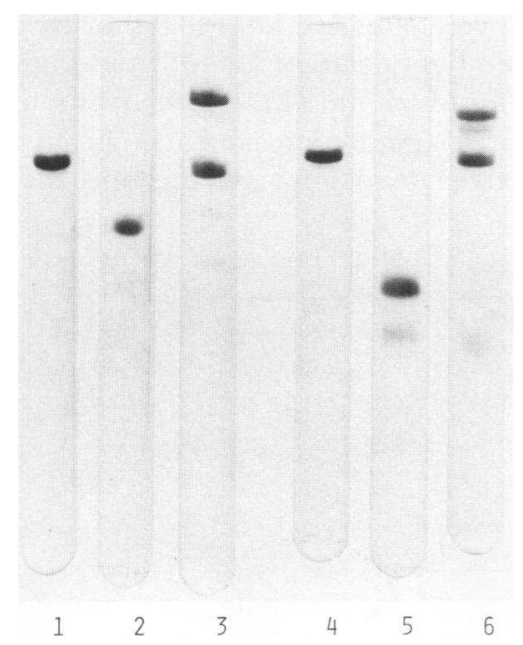

Figure 6 Sodium dodecyl sulfate-polyacrylamide gel electrophoresis pattern of human Factor $\mathrm{IX}_{\mathrm{a} \beta}$ incubated with antithrombin III and heparin. Gels 1 and 4 contain $14 \mu \mathrm{g}$ of antithrombin III before and after reduction with 2 -mercaptoethanol, respectively. Gels 2 and 5 contain $6 \mu \mathrm{g}$ of Factor $\mathrm{IX}_{\mathrm{a} \beta}$ before and after reduction with 2-mercaptoethanol, respectively. Gels 3 and 6 contain Factor IX $_{\mathrm{a} \beta}$ and antithrombin III plus heparin before and after reduction with 2-mercaptoethanol, respectively. In the experiments shown in gels 3 and 6, Factor $\mathrm{IX}_{\mathrm{a} \beta}$ and antithrombin III plus heparin were incubated for $10 \mathrm{~min}$ as described in Methods. In each case $\cong 20 \mu \mathrm{g}$ of protein was applied to $8.5 \%$ polyacrylamide gels. Electrophoresis and staining of the proteins were carried out as described in Methods. The anode was at the bottom of the gels. activated Factor IX formed in the reaction was called Factor IX $\mathrm{X}_{\mathrm{a} \alpha}$. Essentially, no activation of human factor IX by RVV-X-Sepharose occurred in the absence of calcium (solid triangles). RVV-X-Sepharose was employed in these experiments so that the clotting activity of Factor $\mathrm{IX}_{\mathrm{a}}$ could be readily followed after removal of the RVV-X-Sepharose by centrifugation. This was essential because RVV-X readily activates Factor $X$ and this reaction will mask the effect of Factor $\mathrm{IX}_{\mathrm{a}}$ in the clotting assay. The exact concentration of RVV-X in the reaction mixture was not determined. The enzyme-tosubstrate weight ratio was probably $\cong 1: 25$, because unbound RVV-X at this enzyme-to-substrate ratio gave the same gel electrophoresis pattern as described below.

A change in Factor IX during the activation by RVV$\mathrm{X}$-Sepharose was observed by sodium dodecyl sulfatepolyacrylamide gel electrophoresis. Fig. 7 shows the pattern of aliquots removed from the activation mixture at various times and analyzed by gel electrophoresis before and after reduction. At zero time, a single protein band (@mol wt 57,000) was observed, and this band was the major band present after 20-30 min when near maximal Factor IX $_{\mathrm{a} \alpha}$ activity was obtained (Fig. 7, upper panel). The formation of a faster-moving

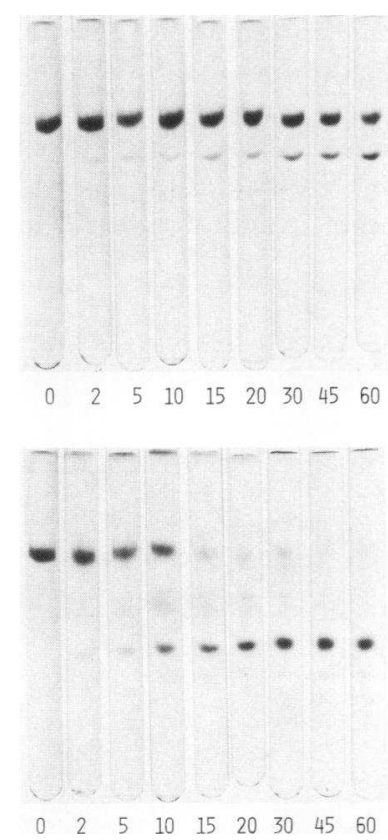

Figure 7 Sodium dodecyl sulfate-polyacrylamide gel electrophoresis pattern of Factor IX activated by RVV-X. Samples ( $\cong 30 \mu \mathrm{g}$ of protein) were removed at various times from the incubation mixtures corresponding to those shown in Fig. 1, and subjected to electrophoresis on $8.5 \%$ polyacrylamide gels as described in Methods. The numbers under the gels refer to the incubation time in minutes. The anode was at the bottom of the gels. The top panel shows the unreduced samples, whereas the bottom panel shows the reduced samples. 
band ( $\cong$ mol wt 46,000 ) was evident in these experiments, however, and this band migrated at a rate identical to Factor IX $\mathrm{X}_{\mathrm{a} \beta}$.

In reduced gels (Fig. 7, lower panel), a new major protein band was observed with an $\cong$ mol wt 28,000. These data suggested that the activation of Factor IX by RVV-X-Sepharose was a result of the cleavage of Factor IX into a two-chain molecule held together by a disulfide bond(s), and this molecule has the same molecular weight as the precursor. Upon reduction, the two-chain molecule is split into two chains that migrate at essentially the same rate on gel electrophoresis.

Evidence for the activation of Factor IX by a single cleavage of an internal peptide bond was shown by amino terminal sequence analysis of a reaction mixture incubated for $\cong 30$ min under conditions analogous to those shown in Fig. 1. Under these conditions, $>80 \%$ of the activated Factor IX was Factor IX IX $\alpha_{\text {and }}<20 \%$ was Factor $\mathrm{IX}_{\mathrm{a} \beta}$ as determined by gel electrophoresis. In the first turn in the amino acid sequencer, valine and tyrosine in equal amounts were identified and little, if any, alanine was present. In subsequent turns, the following residues were identified: asparagine and valine in cycle two, serine and glycine in cycle three, glycine in cycle four, and lysine and glutamic acid in cycle five. These residues correspond to the Tyr-Asn-SerGly-Lys sequence in the amino terminal chain of the precursor molecule and the Val-Val-Gly-Gly-Glu sequence of the heavy chain of Factor IX $\mathrm{IX}_{\mathrm{a} \beta}$ as previously determined. These data indicated that the conversion of human Factor IX to Factor IX a $_{\alpha}$ by RVV-X-Sepharose is a result of the cleavage of a single internal peptide bond, and this bond is the same as that cleaved in Factor IX by Factor $\mathrm{XI}_{\mathrm{a}}$. These data also suggest that Factor IX $_{\mathrm{a} \alpha}$ is converted slowly to Factor $\mathrm{IX}_{\mathrm{a} \beta}$, and this reaction is probably due to the removal of the same activation peptide which is released during the activation of Factor IX by Factor $\mathrm{XI}_{\mathrm{a}}$.

\section{DISCUSSION}

In the present experiments, it has been shown that human Factor IX is readily converted to Factor IX $X_{a \beta}$ in the presence of human Factor $\mathrm{XI}_{\mathrm{a}}$ and calcium ions. This reaction involves a two-step mechanism that is illustrated in Fig. 8. In the first step, an Arg-Ala bond is cleaved by Factor $\mathrm{XI}_{\mathrm{a}}$ giving rise to a two-chain intermediate held together by a disulfide bond(s). This intermediate has no enzymatic activity. In the second step, an Arg-Val bond is cleaved giving rise to an activation peptide and Factor $\mathrm{IX}_{\mathrm{a} \beta}$. These two reactions reduce the molecular weight of the precursor from $\cong 57,000$ to 46,000 . An initial cleavage of human Factor IX by Factor $\mathrm{XI}_{\mathrm{a}}$ may also occur at the Arg-Val bond giving rise to Factor $\mathrm{IX}_{\mathrm{a} \alpha}$. A careful analysis of the intermediates is necessary to clarify the extent of this pathway. In the case of bovine Factor IX, the Arg-Ala bond is cleaved at a far faster rate than the Arg-Val bond (10).

Factor IX $\mathrm{X}_{\mathrm{a} \beta}$ is composed of a light and a heavy chain, and these two chains are held together by a disulfide bond(s). The light chain of Factor $\mathrm{IX}_{\mathrm{a} \beta}$ originates from the amino terminal end of the precursor molecule and contains $\gamma$-carboxyglutamic acid. The heavy chain contains the active site region of the enzyme, and the amino

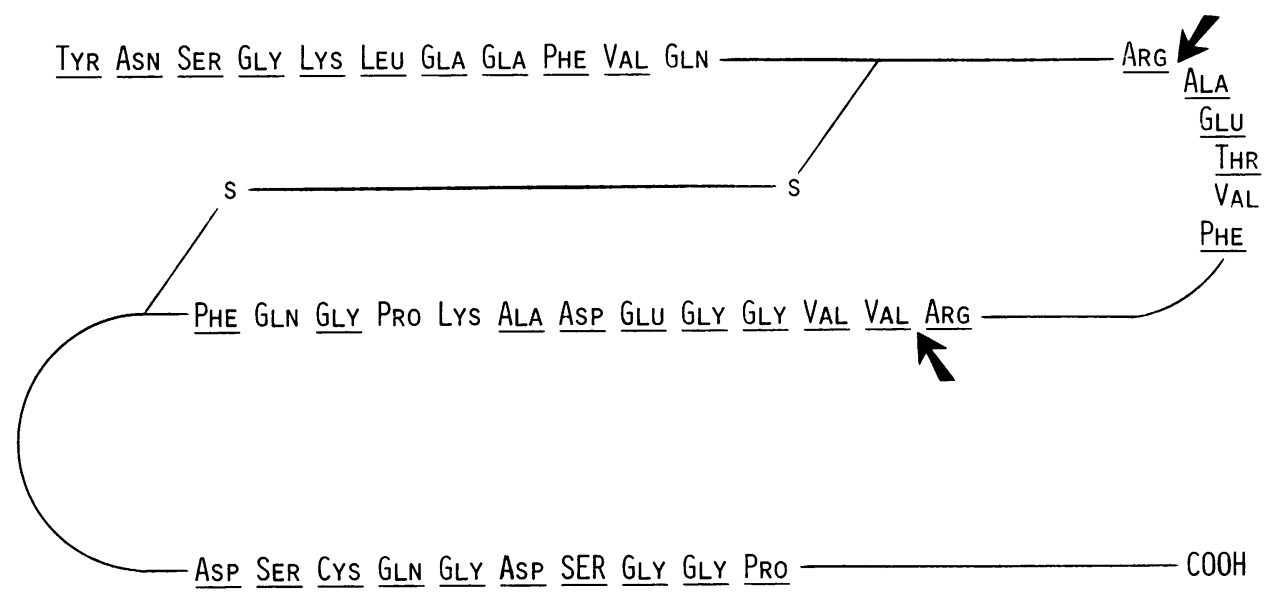

FIGURE 8 Partial structure of human Factor IX. The active site serine residue is shown in large capital letters. Gla refers to $\gamma$-carboxyglutamic acid. Residues that are underlined are identical to those found in bovine Factor IX (38). The two arrows indicate the sites of cleavage in the protein during its conversion to Factor $\mathrm{IX}_{\mathrm{a} \beta}$ by Factor $\mathrm{XI}_{\mathrm{a}}$. The resulting light and heavy chains of Factor $\mathrm{IX}_{\mathrm{a} \beta}$ are held together by a disulfide bond(s). Cleavage of Factor IX by RVV-X occurs primarily at the Arg-Val bond giving rise to Factor $\mathrm{IX}_{\mathrm{a} \alpha}$. Amino acid sequences for the amino terminal region were taken in part from Di Scipio et al. (7) and Fryklund et al. (8) and were confirmed in the present experiments. 
acid sequence in this region shows considerable homology with bovine Factor IX as well as many other plasma serine proteases $(39,40)$.

Human Factor IX is also activated by a protease from RVV-X. This enzyme initially cleaves the internal ArgVal bond giving rise to Factor $\mathrm{IX}_{\mathrm{a} \alpha}$ (Fig. 8). Factor $\mathrm{IX}_{\mathrm{a} \alpha}$ is composed of a heavy and a light chain held together by a disulfide bond(s) and has the same molecular weight as the precursor. Also, it has about the same specific clotting activity as Factor $\mathrm{IX}_{\mathrm{a} \beta}$. With the bovine system, Factor $\mathrm{IX}_{\mathrm{a} \alpha}$ has $\cong 50 \%$ of the clotting activity of Factor $\operatorname{IX}_{\mathrm{a} \beta}$ (11). On prolonged incubation with RVV-X, human Factor $\mathrm{IX}_{\mathrm{a} \alpha}$ undergoes a further cleavage and appears to be converted to Factor $\mathrm{IX}_{\mathrm{a} \beta}$ as determined by sodium dodecyl sulfate-polyacrylamide gel electrophoresis. This reaction, however, was not examined in detail.

The critical event in the activation of Factor IX by Factor $\mathrm{XI}_{\mathrm{a}}$ or RVV-X is the cleavage of the internal Arg-Val bond. This cleavage very likely permits the formation of a new ion pair between the valine residue and the aspartic acid residue adjacent to the active site serine. This would be analogous to the activation mechanism which has been established for the pancreatic serine proteases $(41,42)$. An aspartic acid residue also appears six residues before the active site serine in pancreatic trypsin. This aspartic acid residue is located in the bottom of the binding pocket in this enzyme and is responsible for the specificity of trypsin for peptides containing basic amino acids (43-48). Thus, it seems likely that the specificity of Factor IX $_{\mathrm{a}}$ toward peptides containing a basic amino acid is due to a similar mechanism.

The bond(s) that is cleaved in Factor IX by Factor VII and thromboplastin is not known (12). Also, the exact bond(s) that is cleaved in Factor IX by Factor $\mathrm{X}_{\mathrm{a}}$ has not been established $(11,49)$. It seems likely that the activation of Factor IX by these enzymes also involves the cleavage of the same Arg-Val bond that is cleaved by Factor $\mathrm{XI}_{\mathrm{a}}$ and RVV-X. Factor VII and thromboplastin, as well as RVV-X, also activate Factor X (1). It appears very probable, however, that the primary effect of RVV-X on the clotting of whole plasma is a result of its effect on Factor $\mathrm{X}$ rather than Factor IX. This is indicated by the fact that Factor $\mathrm{X}$ is activated by RVV-X at a rate 10-20 times faster than the activation of Factor IX by RVV-X. Furthermore, the specific activity of Factor $X_{a}$ in a clotting assay is 100-300 times greater than that of Factor $\operatorname{IX}_{\mathrm{a}}(11,50)$, and RVV-X corrects Factor IX-deficient plasma at the same rate as it corrects Factor IXdeficient plasma reconstituted with purified Factor IX. ${ }^{3}$ Whether the major effect of Factor VII and thromboplastin on whole plasma is toward Factor IX or Factor X is not known. It should also be pointed out that the

${ }^{3}$ Di Scipio, R. Unpublished results. primary effect of Factor $X_{a}$ on clotting of plasma is in the activation of prothrombin rather than Factor IX. This is indicated by the high specific activity of Factor $\mathrm{X}_{\mathrm{a}}$ relative to Factor $\mathrm{IX}_{\mathrm{a}}$ in a clotting assay as well as by the fact that Factor $\mathrm{X}_{\mathrm{a}}$ corrects Factor IX-deficient plasma at the same rate as it corrects Factor IX-deficient plasma reconstituted with purified Factor IX. ${ }^{3}$

The effect of antithrombin III on Factor IX $_{\mathrm{a} \beta}$ has also been studied in the present investigations confirming earlier experiments with human and bovine Factor $\operatorname{IX}_{\mathrm{a} \beta}(5,31)$. The present data have also clearly demonstrated the formation of a one-to-one molar complex of enzyme and inhibitor, and the formation of this complex was shown to occur via the heavy chain of the enzyme. The nature of the linkage between enzyme and inhibitor, however, is not known.

\section{ACKNOWLEDGMENTS}

The authors wish to thank Dr. Kazuo Fujikawa for many helpful suggestions during this investigation and for his assistance in the amino acid sequence analyses. Thanks are also owing to Drs. Kouichi Katayama, Koiti Titani, and David Enfield for providing us with amino acid sequence data from bovine Factor IX before publication, and to Richard Granberg for performing the amino acid analyses. The human plasma employed in these investigations was kindly made available by the Puget Sound Blood Center.

This work was supported by research grant HL 16919 from the National Institutes of Health.

\section{REFERENCES}

1. Davie, E. W., and K. Fujikawa. 1975. Basic mechanisms in blood coagulation. Annu. Rev. Biochem. 44: 799-829.

2. Andersson, L-O., H. Borg, and M. Miller-Andersson. 1975. Purification and characterization of human factor IX. Thromb. Res. 7: 451-459.

3. Suomela, H. 1976. Human coagulation factor IX (isolation and characterization). Eur. J. Biochem. 71: 145-154.

4. sterud, B., and R. Flengsrud, 1975. Purification and some characteristics of coagulation factor IX from human plasma. Biochem. J. 145: 469-474.

5. Rosenberg, J., P. McKenna, and R. D. Rosenberg. 1975. Inhibition of human factor $\mathrm{IX}_{\mathrm{a}}$ by human antithrombin. $J$. Biol. Chem. 250: 8883-8888.

6. Thompson, A. R. 1977. Factor IX antigen by radioimmunoassays. J. Clin. Invest. 59: 900-910.

7. Di Scipio, R. G., M. A. Hermodson, S. G. Yates, and E. W. Davie. 1977. A comparison of human prothrombin, factor IX (Christmas factor), factor X (Stuart factor), and protein S. Biochemistry. 16: 698-706.

8. Fryklund, L., H. Borg, and L-O. Andersson. 1976. Aminoterminal sequence of human factor IX: presence of $\gamma$ carboxyl glutamic acid residues. FEBS (Fed. Eur. Biochem. Soc.) Lett. 65: 187-189.

9. Bucher, D., E. Nebelin, J. Thomsen, and J. Stenflo. 1976. Identification of $\gamma$-carboxyglutamic acid residues in bovine factors IX and $X$, and in a new vitamin $K$-dependent protein. FEBS (Fed. Eur. Biochem. Soc.) Lett. 68: 293-296.

10. Fujikawa, K., M. E. Legaz, H. Kato, and E. W. Davie. 1974. The mechanism of activation of bovine factor IX (Christmas factor) by bovine factor $\mathrm{XI}_{\mathrm{a}}$ (activated plasma 
thromboplastin antecedent). Biochemistry. 13: 45084516.

11. Lindquist, P. A., K. Fukikawa, and E. W. Davie. 1978. Activation of bovine factor IX (Christmas factor) by factor $\mathrm{XI}_{\mathrm{a}}$ (activated plasma thromboplastin antecedent) and a protease from Russell's viper venom. J. Biol. Chem. 253: $1902-1909$.

12. $\emptyset$ sterud, B., and S. I. Rapaport. 1977. A bypass mechanism for activating human factor IX with human factor VII and thromboplastin. Thromb. Haemostasis. 38: 179.

13. Wright, I. S. 1959. Nomenclature of blood clotting factors. JAMA (J. Am. Med. Assoc.). 170: 325-328.

14. Фsterud, B., B. N. Bouma, and J. H. Griffin. 1977. Mechanism of activation of human factor IX by activated human factor XI. Thromb. Haemostasis. 38: 14.

15. Kisiel, W., M. A. Hermodson, and E. W. Davie. 1976. Factor X activating enzyme from Russell's viper venom: isolation and characterization. Biochemistry. 15: 49014906.

16. Kurachi, K., G. Schmer, M. A. Hermodson, D. C. Teller, and E. W. Davie. 1976. Characterization of human, bovine, and horse antithrombin III. Biochemistry. 15: $368-373$.

17. Cuatrecasas, P. 1970. Protein purification by affinity chromatography. J. Biol. Chem. 245: 3059-3065.

18. Kurachi, K., and E. W. Davie. 1977. Activation of human factor XI (plasma thromboplastin antecedent) by factor $\mathrm{XII}_{\mathrm{a}}$ (activated Hageman factor). Biochemistry. 16: 5831 5839 .

19. Moore, S., and W. H. Stein. 1963. Chromatographic determination of amino acids by the use of automatic recording equipment. Methods Enzymol. 6: 819-831.

20. Spackman, D. H., W. H. Stein, and S. Moore, 1958. Automatic recording apparatus for use in the chromatography of amino acids. Anal. Chem. 30: 1190-1206.

21. Edelhoch, H. 1967. Spectroscopic determination of tryptophan and tyrosine in proteins. Biochemistry. 6: 19481954.

22. Hirs, C. H. W. 1967. Determination of cystine as cysteic acid. Methods Enzymol. 11: 59-62.

23. Crestfield, A. M., S. Moore, and W. H. Stein. 1963. The preparation and enzymatic hydrolysis of reduced and S-carboxymethylated proteins. J. Biol. Chem. 238: 622627.

24. Friedman, M., L. H. Krull, and J. F. Cavins. 1970. The chromatographic determination of cystine and cysteine residues in proteins as $S-\beta$-(4-pyridylethyl)cysteine. $J$. Biol. Chem. 245: 3868-3881.

25. Warren, L. 1959. The thiobarbituric acid assay of sialic acid. J. Biol. Chem. 234: 1971-1975.

26. Dubois, M., K. A. Gilles, J. K. Hamilton, P. A. Rebers, and F. Smith. 1956. Colorimetric method for determination of sugars and related substances. Anal. Chem. 28: 350-356.

27. Spiro, R. G. 1966. Analysis of sugars found in glycoproteins. Methods Enzymol. 8: 3-5.

28. Gardell, S. 1957. Determination of hexosamines. Methods Biochem. Anal. 6: 289-317.

29. Weber, K., and M. Osborn. 1969. The reliability of molecular weight determinations by dodecyl sulfate-polyacrylamide gel electrophoresis. J. Biol. Chem. 244: 44064412.

30. Roffman, S., V. Sanocka, and W. Troll. 1970. Sensitive proteolytic enzyme assay using differential solubilities of radioactive substance and products in biphasic systems. Anal. Biochem. 36: 11-17.

31. Kurachi, K., K. Fujikawa, G. Schmer, and E. W. Davie. 1976. Inhibition of bovine factor $\mathrm{IX}_{\mathrm{a}}$ and factor $\mathrm{X}_{\mathrm{a} \beta}$ by antithrombin III. Biochemistry. 15: 373-377.
32. Hermodson, M. A., L. H. Ericsson, K. Titani, H. Neurath, and K. A. Walsh. 1972. Application of sequenator analyses to the study of proteins. Biochemistry. 1: 4493-4502.

33. Edman, P., and G. Begg. 1967. A protein sequenator. Eur. J. Biochem. 1: 80-91.

34. Bridgen, P. J., G. A. M. Cross, and J. Bridgen. 1976. Nterminal amino acid sequences of variant-specific surface antigens from Trypanosoma brucei. Nature (Lond.). 263: 613-614.

35. Fraenkel-Conrat, H., J. I. Harris, and A. L. Levy. 1955 Terminal and sequence studies in peptides and proteins. Methods Biochem. Anal. 2: 359-425.

36. Fujikawa, K., M. E. Legaz, and E. W. Davie. 1972. Bovine factors $X_{1}$ and $X_{2}$ (Stuart factor). Isolation and characterization. Biochemistry. 11: 4882-4891.

37. Scheidegger, J. J. 1955. Une micro-méthode de l'immunoélectrophorèse. Int. Arch. Allergy Appl. Immunol. 7: 103-110.

38. Titani, K., D. L. Enfield, K. Katayama, L. H. Ericsson, K. Fujikawa, K. A. Walsh, and H. Neurath. 1977. Primary structure of bovine factor IX. Thromb. Haemostasis. 38: 116.

39. Koide, T., M. A. Hermodson, and E. W. Davie. 1977. Active site of bovine factor XI (plasma thromboplastin antecedent). Nature (Lond.). 266: 729-730.

40. Kisiel, W., K. Fujikawa, and E. W. Davie. 1977. Activation of bovine factor VII (proconvertin) by factor $\mathrm{XII}_{\mathrm{a}}$ (activated Hageman factor). Biochemistry. 16: 41894194.

41. Sigler, P. B., D. M. Blow, B. W. Matthews, and R. Henderson. 1968. Structure of crystalline $\alpha$-chymotrypsin. II. A preliminary report including a hypothesis for the activation mechanism. J. Mol. Biol. 35: 143-164.

42. Stroud, R. M., M. Krieger, R. E. Koeppe, A. A. Kossiakoff, and J. L. Chambers. 1975. Structure-function relationships in the serine proteases. Cold Spring Harbor Conf. Cell Proliferation. 2: 13-32.

43. Mares-Guia, M., and E. Shaw. 1965. Studies on the active center of trypsin. J. Biol. Chem. 240: 1579-1585.

44. Stroud, R. M., L. M. Kay, and R. E. Dickerson. 1974. The structure of bovine trypsin: electron density maps of the inhibited enzyme at $5 \AA$ and at $2 \cdot 7 \AA$ resolution. J. Mol. Biol. 83: 185-208.

45. Ruhlmann, A., D. Kukla, P. Schwager, K. Bartels, and H. Huber. 1973. Structure of the complex formed by bovine trypsin and bovine pancreatic trypsin inhibitor. J. Mol. Biol. 77: 417-436.

46. Blow, D. M., J. Janin, and R. M. Sweet. 1974. Mode of action of soybean trypsin inhibitor (Kunitz) as a model for specific protein-protein interactions. Nature (Lond.). 249: $54-57$.

47. Sweet, R. M., H. T. Wright, J. Janin, C. H. Chothia, and D. M. Blow. 1974. Crystal structure of the complex of porcine trypsin with soybean trypsin inhibitor (Kunitz) at 2.6- $\AA$ resolution. Biochemistry. 13: 4212-4228.

48. Krieger, M., L. M. Kay, and R. M. Stroud. 1974. Structure and specific binding of trypsin: comparison of inhibited derivatives and a model for substrate binding. J. Mol. Biol. 83: 209-230.

49. Kalousek, F., W. Konigsberg, and Y. Nemerson. 1975. Activation of factor IX by activated factor X: a link between the extrinsic and intrinsic coagulation systems. FEBS (Fed. Eur. Biochem. Soc.) Lett. 50: 382-385.

50. Di Scipio, R. G., M. A. Hermodson, and E. W. Davie. 1977. Activation of human factor $X$ (Stuart factor) by a protease from Russell's viper venom. Biochemistry. 16: 5253-5260. 